\title{
Sistem Pendukung Keputusan Penilaian Kelayakan Kredit Menggunakan Metode Simple Additive Weighting (SAW)
}

\author{
Ari Wibowo ${ }^{1^{*}}$, Keanu Kunendra ${ }^{2^{*}}$ \\ * Teknik Informatika, Politeknik Negeri Batam \\ wibowo@polibatam.ac.id ${ }^{1}$, keanu_kunendra@yahoo.com ${ }^{2}$
}

\begin{tabular}{l} 
Article Info \\
\hline Article history: \\
Received 2017-02-04 \\
Revised 2017-10-04 \\
Accepted 2017-10-04 \\
\hline
\end{tabular}

Keyword:

Sistem Pendukung Keputusan, Kelayakan

Kredit,

Simple Additive Weighting

\begin{abstract}
Kredit merupakan peminjaman uang terhadap pihak bank yang biasanya digunakan untuk membangun suatu usaha tertentu. Untuk mendapatkan kredit tentu tidak lepas dari kriteria-kriteria nasabah yang pantas mendapatkan kredit dari pihak bank. Oleh karena itu, tidak semua nasabah bisa mendapatkan kredit. Terkait perihal ini tentu perlu suatu sistem pendukung keputusan (SPK) yang mampu menentukan kelayakan seseorang apakah layak menerima kredit atau tidak, dengan adanya sistem ini maka admin lebih mudah untuk mempertimbangkan dan memperhitungkan kriteriakriteria nasabah yang pantas mendapatkan kredit dari bank. Selain itu dengan adanya SPK tersebut agar sistem pengambilan keputusan nasabah lebih terintegrasi dan memiliki data yang valid. Perhitungan SPK ini didasarkan pada kriteria-kriteria nasabah yang sudah ada pada bank. Pada SPK ini, kriteria-kriteria yang ditentukan oleh bank adalah gaji, tanggungan anak, kemampuan pembayaran, pinjaman lain dan jaminan. Metode yang akan diterapkan pada SPK menggunakan metode Simple Additive Weighting (SAW) serta tool yang digunakan sistem ini adalah komputer. Dengan adanya tool dan metode yang digunakan oleh SPK ini menghasilkan sebuah data yang valid serta data tersebut bisa dicetak langsung oleh admin maupun user. Oleh karena itu, SPK ini bisa digunakan oleh pihak bank karena adanya sistem yang sudah terintegrasi serta memiliki data yang sudah valid.
\end{abstract}

\section{Pendahuluan}

Bank merupakan suatu badan usaha yang mengelola keuangan masyarakat. Menurut Undang-Undang Negara Republik Indonesia Nomor 10 tanggal 10 November 1998 mengenai perbankan, bank merupakan badan usaha yang menghimpun dana dari masyarakat dalam bentuk simpanan dan menyalurkannya kepada masyarakat dalam bentuk kredit ataupun bentuk-bentuk lainnya.

Selain itu, bank juga disebut sebagai lembaga perantara masyarakat yang mengatur adanya kelebihan dana dan kekurangan dana. Pihak yang memiliki kelebihan dana biasanya menanamkan dananya dalam bentuk tabungan, deposito dan lain-lain. Sedangkan, bagi pihak yang mengalami kekurangan dana melakukan peminjaman uang terhadap bank melalui pinjaman atau kredit.

Kredit merupakan salah satu bentuk peminjaman modal dari bank terhadap nasabah atau masyarakat dimana bank memiliki peran untuk menolong masyarakat sehingga bisa dimanfaatkan untuk membangun suatu usaha-usaha secara individu maupun kelompok. Kesulitan yang terjadi dalam pemberian kredit adalah di mana banyaknya kriteria-kriteria yang cocok untuk menentukan kelayakan nasabah mendapatkan kredit. Oleh karena itu, sistem ini membuat dengan 5 karakter umum yaitu character, capacity, capital, condition, colateral.

Sistem Pendukung Keputusan (SPK) merupakan suatu sistem komputer yang dapat membantu pengguna dalam menentukan suatu keputusan [1] di mana mengolah suatu data mentah ataupun dokumen menjadi suatu informasi yang akurat. SPK bisa digunakan secara individu maupun kelompok. Oleh karena, itu SPK sudah cukup umum digunakan untuk mengambil keputusan.

Selain itu, SPK juga dapat meningkatkan efektifitas kinerja, menghemat waktu dan tenaga. Metode yang digunakan adalah metode SAW di mana memiliki kepanjangan yaitu, Simple Additive Weighting (SAW). 
Metode SAW sudah cukup populer pada saat ini untuk membantu pengguna dalam menyelesaikan permasalahan yang ada.

Metode ini juga paling banyak digunakan dalam menghadapi situasi yang memiliki banyak atribut sehingga pengguna pun memiliki kesulitan dalam menentukan keputusan. SAW sangat cocok untuk permasalahan kredit bank. Karena, metode ini memiliki konsep dasar yaitu, mencari penjumlahan terbobot dari rating kriteria pada setiap alternatif pada semua atribut. Selain itu, metode SAW dapat membandingkan dengan semua alternatif yang ada. Oleh karena itu, admin di bagian Mikro Business Unit pun dapat menggunakan sistem ini dengan mudah.

\section{METODE}

Sistem ini menggunakan metode SAW untuk kelayakan pemberian kredit, sistem memiliki dua hak akses yaitu admin mikro dan manajer. Sistem ini dapat mengelola nasabah yang telah mengajukan kredit terhadap bank, mengelola nilai nasabah, mengelola kriteria nasabah, dan mengelola nilai kriteria nasabah. Kriteria yang digunakan oleh sistem ini ada 5 yaitu, character, capacity, capital, condition, dan collateral. Diantara kelima kriteria tersebut yang memiliki atribut benefit adalah kriteria character, capacity dan capital. Sementara itu yang bertindak sebagai atribut cost adalah kriteria condition dan collateral. Masing-masing kriteria memiliki parameterparameter yang sudah ditentukan serta nilai pada setiap masing-masing parameter.

Pada kriteria character menjelaskan tentang kepribadian nasabah tersebut apakah bisa memenuhi janjinya untuk melunasi kreditnya. Pada kriteria capacity, menjelaskan tentang kemampuan nasabah dalam melunasi kreditnya. Pada kriteria capital, menjelaskan tentang kondisi keuangan yang dimiliki nasabah. Pada kriteria condition, menjelaskan tentang kondisi usaha yang dijalankan oleh nasabah tersebut. Pada kriteria collateral, menjelaskan tentang jaminan yang diberikan calon nasabah baik yang bersifat fisik maupun yang non fisik.

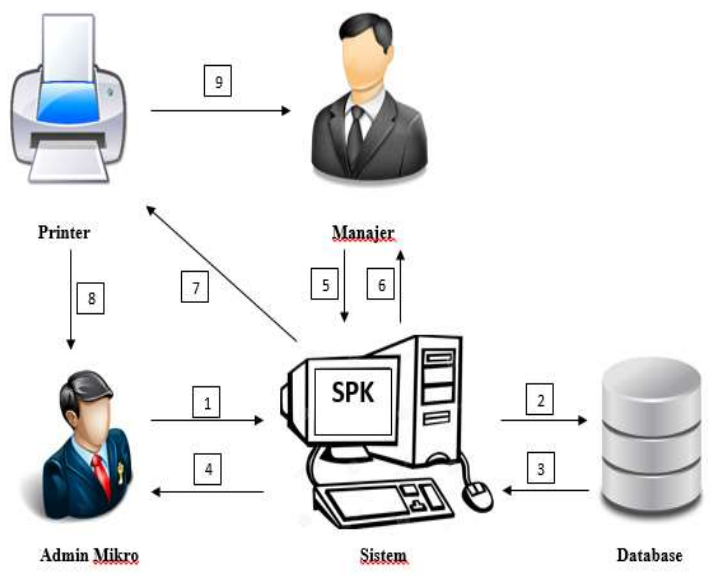

Gambar 1. Deskripsi Umum Sistem
Beberapa penjelasan tentang deskripsi umum sistem antara lain; (1) Login, Kelola Nasabah, Kriteria, Nilai Nasabah, Nilai Kriteria dan Perhitungan SAW. Admin mikro memiliki hak akses ke dalam sistem, kelola data nasabah, kriteria, nilai nasabah, nilai kriteria serta dapat memperhitungkan nasabah dengan menggunakan metode SAW; (2) Simpan Database, sistem menyimpan data inputan ke dalam database; (3) Mengambil data di sistem, sistem mengambil data-data di dalam sistem dari database; (4) Melihat data-data di sistem. Admin mikro dapat melihat data-data di system; (5) Login, melihat data-data di sistem. Manajer memiliki hak akses dan melihat data-data di system; (6) Menampilkan data-data di sistem. Sistem dapat menampilkan data-data; (7) Sistem mencetak hasil laporan data nasabah. Sistem dapat mencetak hasil laporan data nasabah yang sudah diperhitungkan oleh admin mikro; (8) Admin mikro melihat hasil cetakan laporan data nasabah. Admin mikro melihat laporan data nasabah yang sudah dicetak; (9) Manajer melihat hasil cetakan laporan data nasabah. Manajer melihat laporan data nasabah yang sudah dicetak.

\section{Perancangan}

Perancangan sistem dilakukan dengan membuat usecase diagram, ER diagram dan class diagram dari sistem.

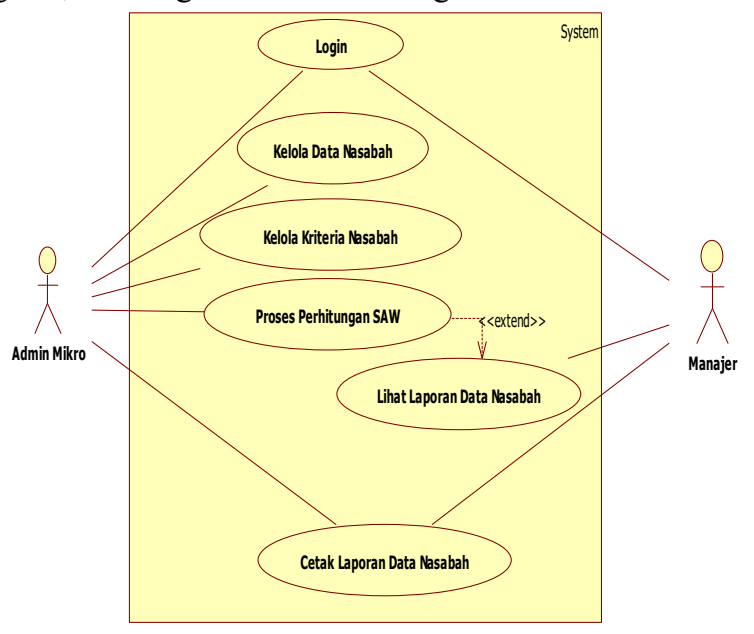

Gambar 2. Usecase Diagram

Sistem ini memiliki dua user yaitu, admin mikro dan manajer. Admin memiliki hak akses untuk login, kelola data nasabah, kelola kriteria nasabah, proses perhitungan SAW, lihat laporan data nasabah dan cetak laporan data nasabah. Manajer tidak memiliki hak akses untuk login, lihat laporan data nasabah dan cetak laporan data nasabah. Admin memberikan kriteria nasabah yang layak mendapatkan kredit. Kemudian memberikan parameter pada setiap kriteria yang ada serta nilai pada setiap masing-masing kriteria. Selanjutnya admin memasukkan data nasabah yang telah mengajukan kredit pada bank. Admin memasukkan kriteria pada setiap nasabah yang telah mengajukan kredit, lalu sistem memutuskan kelayakan pemberian kredit menggunakan metode SAW dengan melampirkan hasil data nasabah yang layak mendapatkan kredit. 


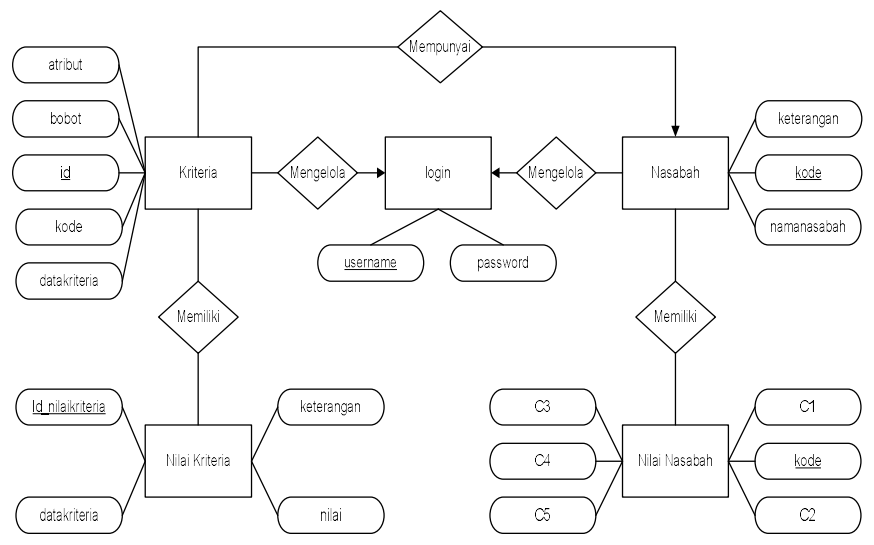

Gambar 3. ER Diagram

ER Diagram sistem yang dirancang memiliki 5 tabel utama yaitu tabel login, kriteria, nilai kriteria, nasabah dan nilai nasabah. Pada tabel login, memiliki 2 atribut yaitu username sebagai primary key dan password. Pada tabel kriteria, memiliki 5 atribut yaitu id sebagai primary key, kode, data kriteria, bobot dan atribut. Pada tabel nilai kriteria, memiliki 4 atribut yaitu id nilaikriteria sebagai primary key, data kriteria, keterangan dan nilai. Pada tabel nasabah, memiliki 3 atribut yaitu, kode sebagai primary key, keterangan dan nama_nasabah. Pada tabel nilai nasabah, memiliki 6 atribut yaitu kode sebagai primary key, C1, C2, C3, C4 dan C5.

Dimana satu user dapat mengelola banyak kriteria dan dapat mengelola banyak nasabah. Banyak kriteria memiliki banyak nilai kriteria begitu juga dengan banyak nasabah memiliki banyak nilai nasabah serta, satu nasabah memiliki banyak kriteria.

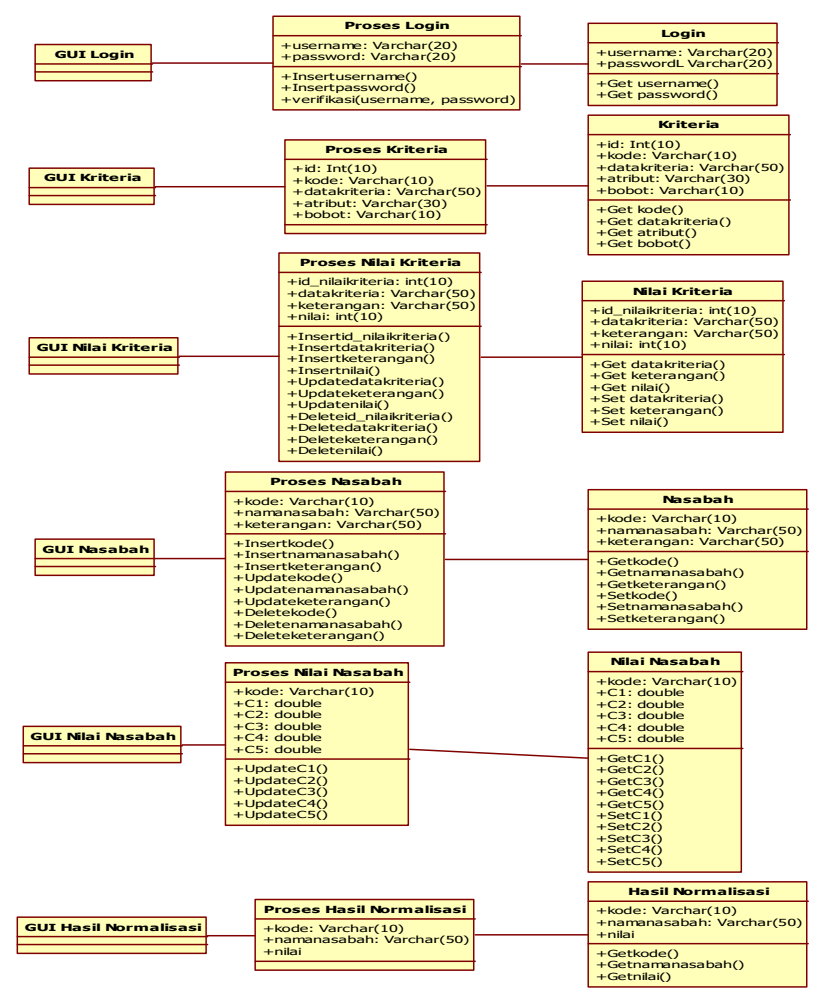

Gambar 4. Class Diagram
Diagram class memiliki 6 tabel yaitu login, kriteria, nilai kriteria, nasabah, nilai nasabah serta hasil normalisasi. Pada masing-masing tabel sudah didefinisikan atribut-atribut, type data yang digunakan serta fungsi pada atribut itu sendiri.

\section{HASIL DAN IMPLEMENTASI}

Sistem ini menggunakan metode SAW untuk kelayakan pemberian kredit, sistem memiliki dua

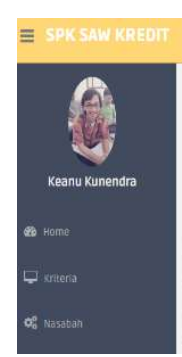

Sistem Pendukung Keputusan Pemberian Kredit Menggunakan Metode SAW

Kredit adalah salah satu bentuk peminjaman modal dari bank terhadap nasabah atau masyarakat di

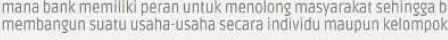

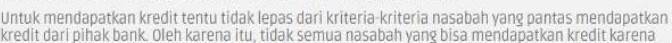

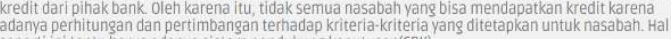

Gambar 5. Halaman Awal

Halaman awal pada sistem pendukung keputusan di mana ada penjelasan sedikit tentang kredit, sistem pendukung keputusan serta kriteria yang digunakan oleh sistem.

TABEL I

NiLAI NASABAH

\begin{tabular}{|c|c|c|c|c|c|}
\hline $\begin{array}{c}\text { Pendaftar } \\
\text { /Kriteria }\end{array}$ & C1 & C2 & C3 & C4 & C5 \\
\hline $\mathbf{A 1}$ & 5 & 50 & 50 & 75 & 50 \\
\hline $\mathbf{A 2}$ & 75 & 50 & 100 & 50 & 75 \\
\hline $\mathbf{A 3}$ & 25 & 50 & 25 & 75 & 100 \\
\hline $\mathbf{A 4}$ & 75 & 25 & 5 & 75 & 100 \\
\hline $\mathbf{A 5}$ & 75 & 25 & 25 & 100 & 75 \\
\hline
\end{tabular}
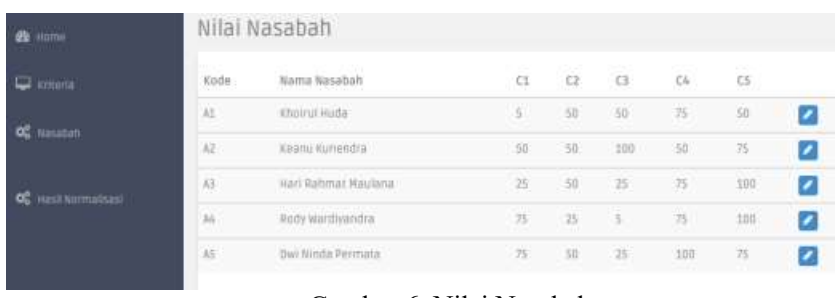

Gambar 6. Nilai Nasabah

Implementasi antarmuka nilai nasabah, di mana admin dapat mengelola kriteria-kriteria pada setiap nasabah lalu di munculkan data matriks di dalam tabel.

TABEL III

NILAI BOBOT

\begin{tabular}{|c|c|cc|c|c|c|}
\hline Nilai Bobot & 0.20 & 0.35 & 0.25 & 0.10 & 0.10 \\
\hline \\
$\left(\begin{array}{ccccc}5 & 50 & 50 & 75 & 50 \\
75 & 50 & 10050 & 75 \\
25 & 50 & 2575 & 100 \\
75 & 25 & 575 & 100 \\
75 & 25 & 25100 & 75\end{array}\right)$
\end{tabular}

Karena, kriteria 1 sampai dengan kriteria 3 dinyatakan benefit dan kriteria 4 dan 5 adalah cost maka perumusannya adalah sebagai berikut. 


$$
\left(\begin{array}{ccccc}
r_{11}=\frac{5}{75}=0.067 & r_{12}=\frac{50}{50}=1 & r_{13}=\frac{50}{100}=0.5 r_{14}=\frac{75}{100}=0.75 & r_{15}=\frac{50}{100}=0.5 \\
r_{21}=\frac{75}{75}=1 & r_{22}=\frac{50}{50}=1 & r_{23}=\frac{100}{100}=1 r_{24}=\frac{50}{100}=0.5 & r_{25}=\frac{75}{100}=0.75 \\
r_{31}=\frac{25}{75}=0.33 & r_{32}=\frac{50}{50}=1 & r_{33}=\frac{25}{100}=0.25 r_{34}=\frac{75}{100}=0.75 & r_{35}=\frac{100}{100}=1 \\
r_{41}=\frac{75}{75}=1 & r_{42}=\frac{25}{50}=0.5 & r_{43}=\frac{5}{100}=0.05 r_{44}=\frac{75}{100}=0.75 & r_{45}=\frac{100}{100}=1 \\
r_{51}=\frac{75}{75}=1 & r_{52}=\frac{25}{50}=0.5 & r_{53}=\frac{25}{100}=0.25 r_{54}=\frac{100}{100}=1 & r_{55}=\frac{75}{100}=0.75
\end{array}\right)
$$

Setelah dihitung, akan mendapatkan hasil seperti ini.

$$
\left(\begin{array}{llllll}
0.067 & 1 & \multicolumn{2}{l}{0.5} & 0.75 & 0.5 \\
1 & 1 & & 10.5 & 0.75 \\
0.33 & 1 & 0.250 .75 & 1 \\
1 & 0.5 & 0.050 .75 & 1 \\
1 & 0.5 & & 0.251 & 0.75
\end{array}\right)
$$

Selanjutnya hitung nilai tersebut dengan nilai bobot yang sudah ditentukan.

$$
\left(\begin{array}{lllll}
0.20 & 0.35 & 0.25 & 0.10 & 0.10
\end{array}\right)
$$

$$
\begin{aligned}
& (0.067 * 0.20)+(1 * 0.35)+(0.5 * 0.25)+(0.75 * 0.10)+(0.5 * 0.10)) \\
& \left(\begin{array}{ccccc}
(1 * 0.20)+ & (1 * 0.35) & +(1 * 0.25)+(0.5 * 0.10) & +(0.75 * 0.10) \\
(0.33 * 0.20)+(1 * 0.35) & +(0.25 * 0.25)+(0.75 * 0.10)+(1 * 0.10)
\end{array}\right.
\end{aligned}
$$

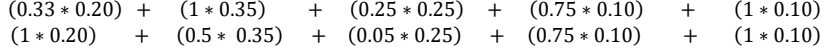

$$
\begin{aligned}
& \left(\begin{array}{l}
(1 * 0.20)+(0.5 * 0.35)+(0.05 * 0.25)+(0.75 * 0.10)+(1 * 0.10) \\
(1 * 0.20)+(0.5 * 0.35)+(0.25 * 0.25)+(1 * 0.10)+(0.75 * 0.10)
\end{array}\right)
\end{aligned}
$$

Diperoleh hasil penjumlahan sebagai berikut.

$$
\begin{aligned}
& A 1=0.0134+0.35+0.125+0.075+0.05=0.61 \\
& A 2=0.20+0.35+0.25+0.05+0.075=0.93 \\
& A 3=0.066+0.35+0.0625+0.075+0.10=0.65 \\
& A 4=0.20+0.175+0.0125+0.075+0.10=0.56 \\
& A 5=0.20+0.175+0.0625+0.10+0.075=0.61
\end{aligned}
$$

Maka, dapat disimpulkan bahwa A2 layak mendapatkan kredit.

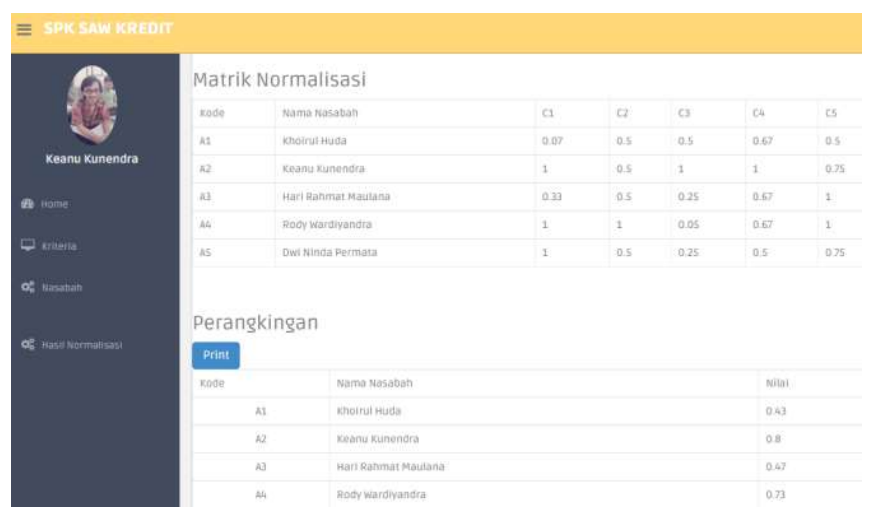

Gambar 7. Implementasi Antarmuka dan Perangkingan

Implementasi antarmuka hasil normalisasi, di mana terdapat dua tabel yaitu, tabel matrik normalisasi dan tabel perangkingan.

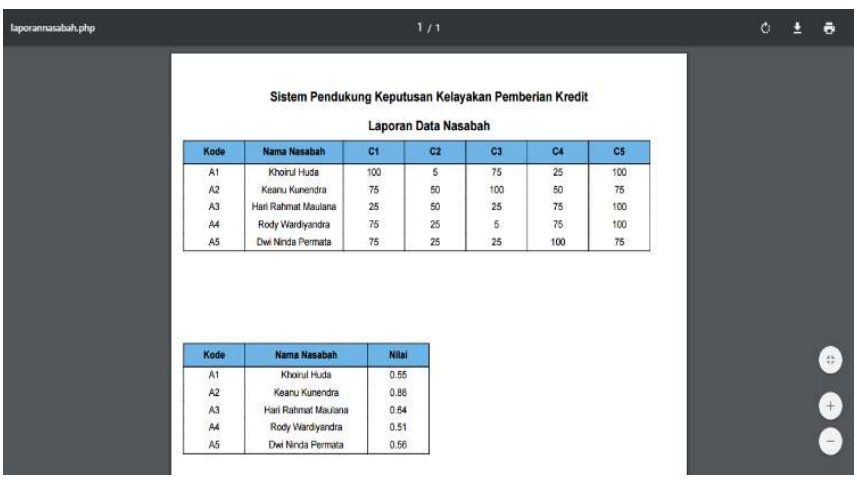

Gambar 7. Implementasi Antarmuka Laporan Nasabah

Halaman laporan nasabah merupakan cetak laporan hasil perangkingan dari perhitungan SAW dari sistem tersebut. Cetak laporan berupa file pdf.

\section{KESIMPULAN}

Dari hasil perancangan dan implementasi sistem pendukung keputusan diperoleh kesimpulan bahwa:

1. Sistem pendukung keputusan berhasil menghitung dan merangking data nasabah dengan penjumlahan terbobot dari Simple Additive Weighting (SAW).

2. Sistem ini berhasil mengelola data kriteria dan data nasabah.

3. Sistem ini dapat mencetak hasil laporan data nasabah yang sudah dirangking dengan luaran berupa file pdf sebagai laporan keputusan pemberian kredit.

\section{DAFTAR PUSTAKA}

[1] Kurniawan, D. E., \& Pujiyono, P. (2016). Sistem Pendukung Keputusan Pemilihan Pemasok Bahan Baku Menggunakan Metode Technique for Order Preference by Similarity to Ideal Solution. Jurnal Integrasi, 8(1), 56-60.

[2] Kurniawan, D. E., \& Amanda, S. T. (2017). Pemilihan Rumah Menggunakan Metode Weight Product Dengan Visualisasi Lokasi Objek. Klik-Kumpulan Jurnal Ilmu Komputer, 4(1), 102-111.

[3] Didik, A, 2015. "Pengertian HTML Fungsi HTML dan Contoh HTML". Jawa Timur.

[4] Andre, 2014. "Pengertian dan Fungsi PHP dalam Pemrograman Web". DuniaIlkom. Surabaya.

[5] Suhari, Y., Sujur, M., dan Eniyati, Sri, 2009. "Sistem Pendukung Keputusan Pemberian Kredit Pada Pt. BPR Artamanunggal Abadi Mranggen". Fakultas Teknologi Informasi. Universitas Stikubank, Semarang.

[6] Subagiyo, T, 2010. "Aplikasi Kelayakan Pemberian Kredit untuk Calon Nasabah

[7] Menggunakan Metode TOPSIS". Fakultas Teknologi Informasi. Universitas Pembangunan Nasional "Veteran", Jawa Timur.

[8] Napita, D 2014. "Sistem Pendukung Keputusan Kelayakan Pemberian Kredit di Pt. BPR Delanggu Raya”.Amikom Yogyakarta. Sekolah Tinggi Manajemen Informatika dan Komputer, Yogyakarta.

[9] Muhammad, B, 2013. "Penerapan Metode Sistem Pendukung Keputusan (SAW)". Jakarta.

[10] Kurniawan, D. E. (2015). Handout Kuliah Sistem Informasi, Perpustakaan Politeknik Negeri Batam 